\title{
Designing Invasion-Resistant Plant Communities: The Role of Plant Functional Traits
}

\section{By Rebecca E. Drenovsky and Jeremy J. James}

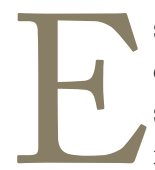

stablishing and maintaining weed-resistant plant communities is a central goal of sustainable invasive plant management. ${ }^{1}$ Based on this need, much research has been directed toward understanding properties that confer plant community invasion resistance. Early work identified a positive relationship between resource availability and an invader's ability to establish and spread in native plant communities. ${ }^{2}$ This work led researchers and managers to question how plant community composition influences resource availability and invasion resistance.

Initial efforts focused on the impact of the number of species present (i.e., species richness) and/or the number of species present as well as their relative abundances (i.e., species diversity). Although some research found that increasing species richness or diversity decreased resource availability and increased invasion resistance, most evidence suggested species richness and diversity were relatively poor predictors of invasion resistance. ${ }^{3}$ One reason was the high degree of functional overlap between species. For example, researchers found that different perennial bunchgrass species tended to have similar patterns of resource capture, suggesting there was some functional redundancy in how these species influenced resource availability. ${ }^{4}$ Similar relationships were found between different shrub and perennial forbs species. As a result, researchers and managers began focusing on coarse functional groups (e.g., perennial grasses, forbs, shrubs) rather than on individual species. With this approach, the array of species in a plant community was condensed into only a handful of functional groups.

Unfortunately, more than two decades of research indicates that neither species diversity nor functional group diversity adequately predict invasion resistance. In most cases it appears that a single species or functional group is the major driver of invasion resistance, with the species or functional group varying across different invasion scenarios. ${ }^{5,6}$ At the outset, this observation can be frustrating to managers, causing them to ask the reasonable question: "Which species or functional group should my management target?" To answer this question, we need to focus less on the identity of the species, initially, and more on the suite of functional traits shared by species that are able to successfully resist invasion. The burning question is, "Which functional traits are important?" Fortunately, there are some very timely answers to this question.

\section{Current Knowledge}

Over the last several years, researchers around the globe have been independently investigating this exact question and surprisingly arriving at very similar conclusions. Although there are over 260,000 known vascular plant species, one simple spectrum of plant traits can describe and predict the major differences in their ecological strategies. ${ }^{7,8}$ If we can place a particular invader along this spectrum, we may be able to predict which native species would have the greatest ability to interfere with its establishment and spread. This spectrum differentiates plants based on traits allowing rapid resource capture vs. resource conservation (Fig. 1) and is built on the concept of (plant) economics. For plants, the main unit of currency is carbon. It is what plants capture during photosynthesis and the main building block for leaf, stem, and root tissue. Therefore, differences in how plants use carbon to construct plant tissue drives the major differences in plant ecological strategies. At one end of the tissue economics spectrum are plants that construct less dense, poorly protected leaf and root tissue. This strategy permits rapid growth and resource capture but makes plants very susceptible to losing resources through herbivory or environmental stress. On the other end of the spectrum are plants that construct dense, well-protected leaf and root tissue. This strategy reduces plant growth and resource capture rates but allows plants to conserve the resources they have captured.

This trade-off between growth and resource conservation has large implications for resource acquisition and use. Obviously, storing a large proportion of acquired resources will slow growth; similarly, producing dense, well-protected roots and shoots also will slow growth. In contrast, 


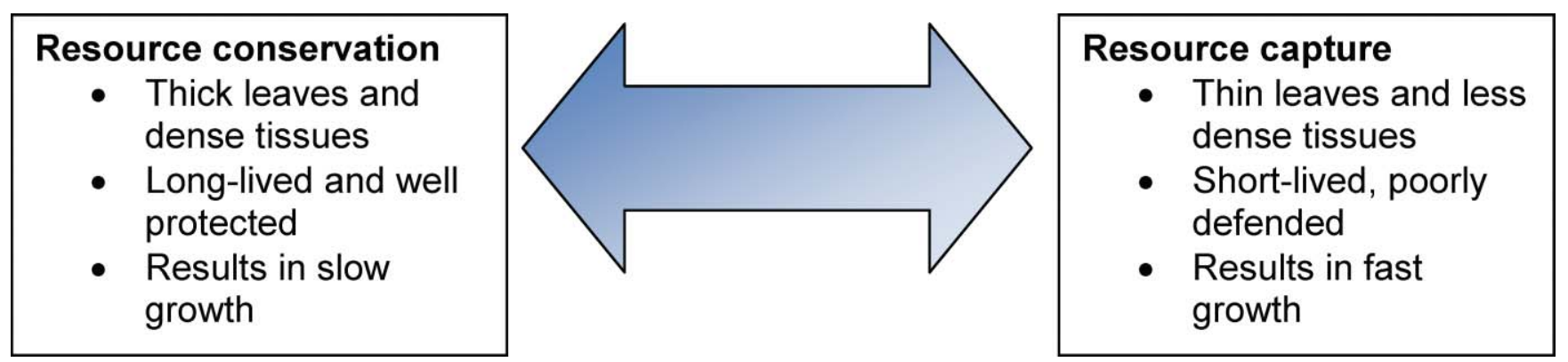

Figure 1. Spectrum of leaf economic strategies ranging from rapid resource capture to efficient resource conservation.

allocating carbon to produce "cheap" roots quickly increases root mass for nutrient and water capture and thus may enable resource preemption by a fast-growing species. However, there is a trade-off here, as well. Allocating a large proportion of resources to roots does not directly improve future carbon gain. On the other hand, investing carbon in "cheap" leaves (meaning they contain less structural material such as lignin) increases the plant's ability to capture more carbon in the future. In doing so, a plant can make more leaf area with the same unit of carbon compared to plants that make thicker leaves, and as a result, realize a greater rate of return on their carbon investment (Fig. 2). Given this observation, the following is a logical series of questions: 1) How do native and invasive species differ in their resource capture strategies? 2) Is there variation in these traits among native species? 3) If so, can we use this information to improve our ability to design weed-resistant plant communities? 4) Can we make predictions as to under what types of conditions these different strategies would be promoted?

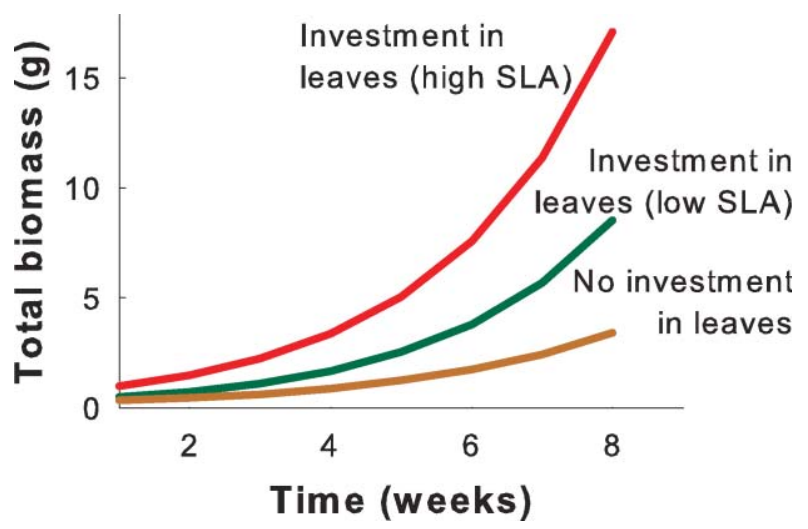

Figure 2. Economic investment model for plant carbon. The brown line represents biomass produced through time if a plant allocates all new carbon fixed in photosynthesis to roots. The green line represents biomass produced through time if a plant uses some of the new carbon fixed during photosynthesis to make thick (low specific leaf area [SLA]) leaves. The red line represents biomass produced through time if a plant uses some of the new carbon fixed during photosynthesis to make thin (high SLA) leaves.

\section{Current Rangeland Research}

We have initiated a series of studies that provide some insight into these questions. ${ }^{9,10} \mathrm{We}$ used a comparative approach that included native and invasive perennial forbs, native and introduced bunchgrasses, and invasive annual grasses (Table 1). Multiple species were included within each functional group, allowing us to examine variation in key traits within and among groups. Based on the tissue economics spectrum described above, we examined variation in leaf thickness and root growth among these species groups and how variation in these traits influenced resource capture and plant growth. Leaf thickness was measured as leaf area produced per unit biomass invested in leaf (specific leaf area [SLA]). A higher SLA indicates thinner tissue and thus "cheaper" leaves. Given the low nutrient availability commonly found on rangelands, we also examined traits related to root nutrient capture and traits related to how efficiently nutrients were used to support plant growth. We used two different analytical approaches for answering our questions. First, we used path analysis to examine the relationship among traits when all species were grouped together. In its simple form, path analysis allows us to examine correlations among variables, enabling us to answer questions such as, "Considering all species grouped together, which trait is most important for nitrogen capture or plant growth?" We also used analysis of variance to ask questions such as, "Do different groups of species (e.g., native forbs and invasive forbs) differ in a trait?"

Growth rate is influenced by net assimilation rate, which is the balance between photosynthesis and respiration rates, and leaf area ratio, the amount of leaf area per unit total plant mass. Leaf area ratio, in turn, is influenced by leaf mass ratio, which is the proportion of biomass the plant allocates to leaves, and SLA. Our path analysis showed that differences in SLA were the central factor driving differences in growth rate among species (Fig. 3); species constructing thinner leaves (higher SLA) grew faster. In some cases, invasive species produced much thinner leaves than natives (Fig. 4), allowing them to produce more overall leaf area (Fig. 5) at a "cheaper" cost to the plant. However, some native species achieved SLA and growth rates that were greater than or comparable to their native counterparts 


\begin{tabular}{|c|c|c|c|}
\hline Group & Common name & Species & $\begin{array}{c}\text { Species } \\
\text { abbreviation }\end{array}$ \\
\hline \multirow[t]{6}{*}{ Native forbs } & Common yarrow & Achillea millefolium L. var. occidentalis DC. & ACMI \\
\hline & Common woolly sunflower & Eriophyllum lanatum (Pursh) Forbes & ERLA \\
\hline & Rocky mountain penstemon & Penstemon strictus Benth. & PEST \\
\hline & Western hawksbeard & Crepis occidentalis Nutt. & CROC \\
\hline & Blue flax & Linum lewisii Pursh & LILE \\
\hline & Munro globemallow & Sphaeralcea munroana (Dougl. ex Lindl.) & SPMU \\
\hline \multirow[t]{6}{*}{ Invasive forbs } & Spotted knapweed & Centaurea stoebe L. & CEST \\
\hline & Rush skeletonweed & Chondrilla juncea L. & CHJU \\
\hline & Dalmatian toadflax & Linaria dalmatica (L.) P. Mill. & LIDA \\
\hline & Whitetop & Cardaria draba (L.) Desv. & CADR \\
\hline & Common teasel & Dipsacus fullonum L. & DIFU \\
\hline & Scotch thistle & Onopordum acanthium L. & ONAC \\
\hline \multirow{2}{*}{$\begin{array}{l}\text { Native perennial } \\
\text { grasses }\end{array}$} & Bluebunch wheatgrass & Pseudoroegenaria spicata (Pursh) A. Löve & PSSP \\
\hline & Bottlebrush squirreltail & Elymus elymoides (Raf.) Swezey & ELEL \\
\hline $\begin{array}{l}\text { Introduced perennial } \\
\text { grass }\end{array}$ & Crested wheatgrass & $\begin{array}{l}\text { Agropyron desertorum (Fisch. ex Link) J. A. } \\
\text { Schultes }\end{array}$ & AGDE \\
\hline \multirow{3}{*}{$\begin{array}{l}\text { Invasive annual } \\
\text { grasses }\end{array}$} & Cheatgrass & Bromus tectorum L. & BRTE \\
\hline & Medusahead & Taeniatherum caput-medusae (L.) Nevski & TACA \\
\hline & Ventenata & Ventenata dubia (Leers) Coss. & VEDU \\
\hline
\end{tabular}

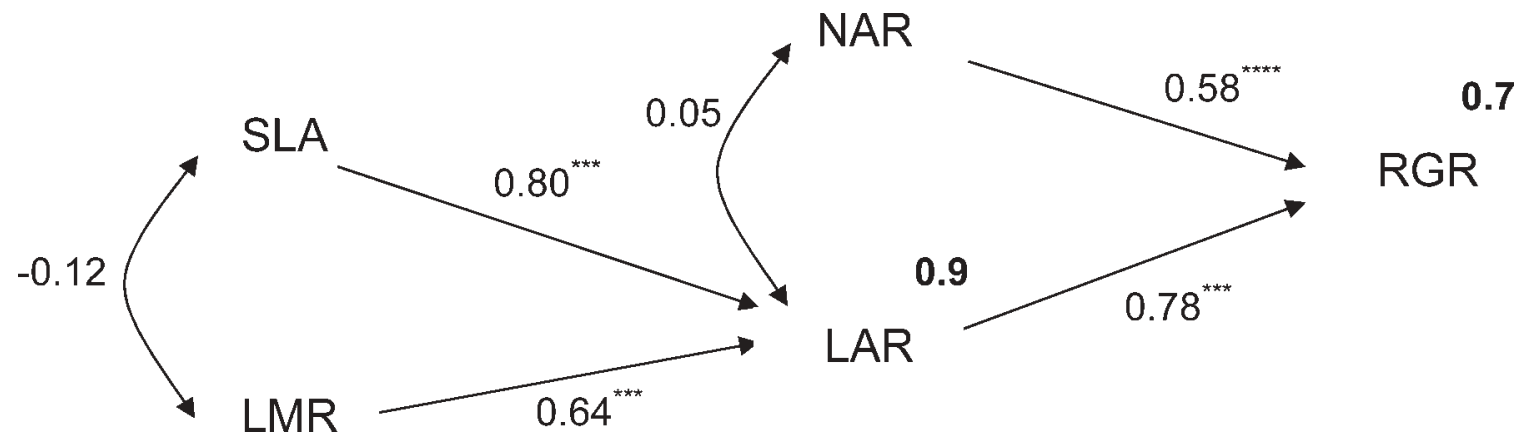

Figure 3. Path model describing how variation in net assimilation rate (NAR), leaf area ratio (LAR), specific leaf area (SLA), and leaf mass ratio (LMR) influences variation in relative growth rate (RGR) of native and invasive forbs. For each path effect, the standardized partial regression coefficient is given and the significance of the path is indicated as ${ }^{* *} P<0.0001$. Numbers in bold are the total variance explained $\left(r^{2}\right)$ for each dependent variable. Measurements were quantified across four harvests spaced in 2-week intervals. Figure reprinted with permission from SRM. Data are from James and Drenovsky. ${ }^{9}$ 


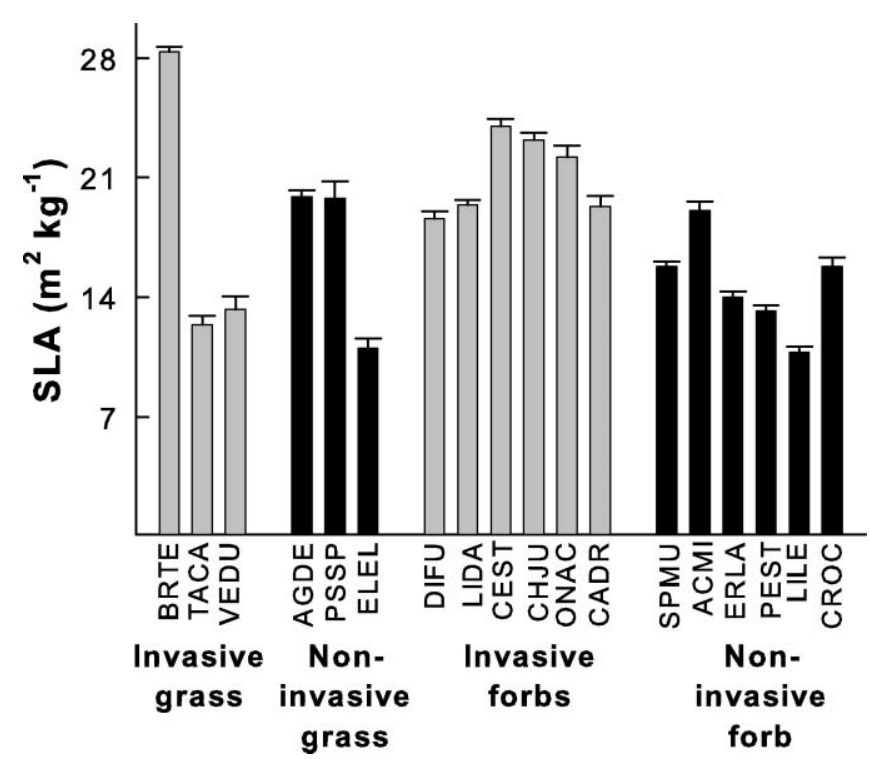

Figure 4. Specific leaf area (SLA) of the study species (mean $\pm S E$ ). Species abbreviations follow Table 1. Invasive species have gray bars. Redrawn figure reprinted with permission from SRM. Forb data are from James and Drenovsky. ${ }^{9}$

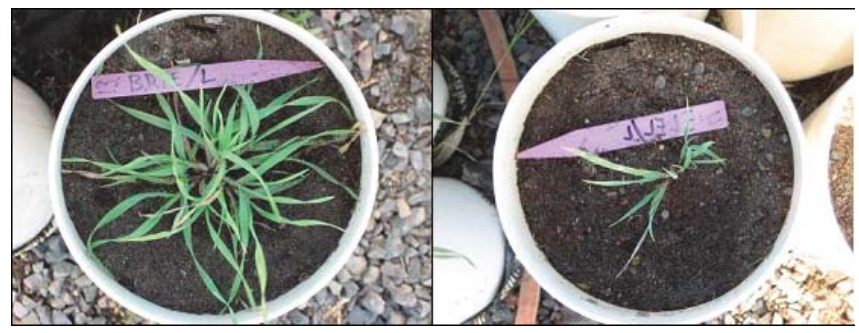

Figure 5. Leaf area production of Bromus tectorum (left) and Elymus elymoides (right). Biomass allocation to roots and leaves were similar between these species, but Bromus tectorum had a higher specific leaf area than Elymus elymoides (Fig. 4).

(Fig. 4). Therefore, establishing subsets of native species with high SLA in a community may be one way to increase invasion resistance. These plants have constructed "cheap" biomass, allowing them to attain higher growth rates.

These measurements of leaf thickness and growth, however, do not provide information about how these groups of species capture and use nutrients. Many of the most serious invaders can establish on undisturbed, nutrient-poor rangeland soils, suggesting invader success and invasion resistance also may be conferred by nutrient uptake and use characteristics. We grew native and invasive plants in pots in which soil nutrients were distributed evenly or unevenly in patches. We found that invasives tended to have a greater ability to detect areas in the soil where nutrients were located (Fig. 6) and use these nutrients more efficiently in photosynthesis (Fig. 7). Together, these traits are a double-edged sword that may greatly contribute to the success of invasives on nutrient-poor rangelands. Invaders

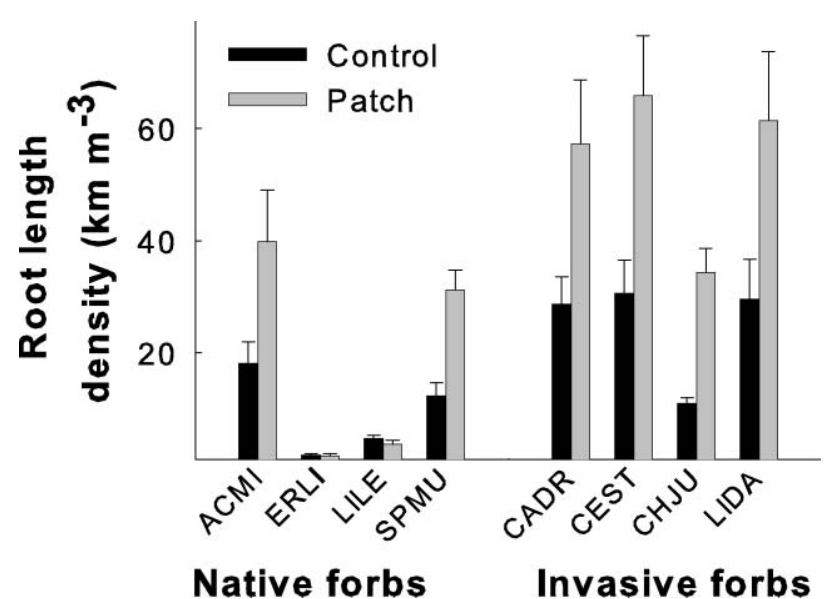

Figure 6. Root length density of native and invasive forbs grown in pots with nutrients distributed evenly in a low concentration (control) or with nutrients concentrated in small patches (patch; mean $\pm S E$ ). Species abbreviations follow Table 1. Figure reprinted with permission from the Botanical Society of America. Data are from Drenovsky et al. ${ }^{10}$

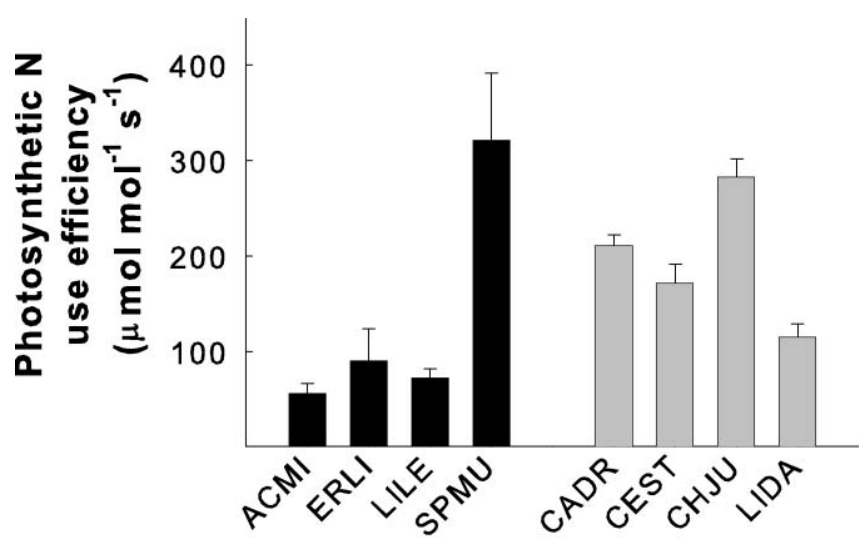

Native forbs

Invasive forbs

Figure 7. Photosynthetic nitrogen use efficiency of native and invasive forbs (mean \pm SE). Species abbreviations follow Table 1. Redrawn figure reprinted with permission from the Botanical Society of America. Data are from Drenovsky et al. ${ }^{10}$

use roots more efficiently to capture soil nutrients, and they actually need less of these nutrients to maintain the same level of photosynthetic rate compared to many of our natives.

One important aspect of this data set is the highly variable responses observed among the native species (Table 2). For most traits measured, the coefficient of variation was up to 3.4-fold greater within native than within invasive groups. In other words, some native species, such as Achillea millefolium and Sphaeralcea munroana, had functional trait values similar to the invasive species (e.g., high SLA and high photosynthetic nitrogen use efficiencies), whereas other native species, such as Linum lewisii and Erigeron linearis, did not. The implications of these trait differences for 
Table 2. Coefficients of variation for RGR, SLA, and nutrient use and acquisition traits measured for native and invasive forbs. Species replicates for RGR and SLA were based on values for each harvest interval. Data reprinted with permission from the Botanical Society of America. Data are from Drenovsky et al. ${ }^{10}$

\begin{tabular}{|c|c|c|}
\hline Trait & Native CV & Invasive CV \\
\hline RGR (g/g/day) & 50.1 & 26.7 \\
\hline $\operatorname{SLA}\left(\mathrm{m}^{2} / \mathrm{kg}\right)$ & 23.8 & 22.6 \\
\hline $\begin{array}{l}\text { Total aboveground } \\
\text { biomass (g) }\end{array}$ & 120.4 & 35.4 \\
\hline $\begin{array}{l}\text { Total belowground } \\
\text { biomass }(\mathrm{g})\end{array}$ & 132.1 & 52.9 \\
\hline Root mass ratio (\%) & 28 & 37.4 \\
\hline $\begin{array}{l}\text { Root length density } \\
\left(\mathrm{km} / \mathrm{m}^{3}\right)\end{array}$ & 90.5 & 58.3 \\
\hline Leaf nitrogen $(\mathrm{g} / \mathrm{kg})$ & 16.2 & 21.2 \\
\hline $\begin{array}{l}\text { Leaf phosphorus } \\
(\mathrm{g} / \mathrm{kg})\end{array}$ & 25.3 & 47.2 \\
\hline $\begin{array}{l}\text { Photosynthetic } \\
\text { assimilation rate } \\
\left(\mu \mathrm{mol} / \mathrm{m}^{2} / \mathrm{s}\right)\end{array}$ & 65.1 & 23.5 \\
\hline $\begin{array}{l}\text { Photosynthetic } \\
\text { nitrogen use efficiency } \\
\text { ( } \mu \mathrm{mol} / \mathrm{mol} / \mathrm{s})\end{array}$ & 106.6 & 36.9 \\
\hline
\end{tabular}

$\mathrm{CV}$ indicates coefficient of variation; RGR, relative growth rate; and SLA, specific leaf area.

designing invasion-resistant plant communities are significant. From these data, we would predict that invasion resistance would be poor if a low SLA, low nitrogen-useefficiency native forb was paired against a high SLA, high nitrogen-use-efficiency invasive forb. In contrast, we would predict that invasion resistance would be improved if a high SLA, high nitrogen-use-efficiency native forb was paired with the invasive forb. Given these predictions, the next step is to test them under field conditions.

From this relatively simple data set containing only a handful of species, we can see how conventional species groupings (e.g., forbs, shrubs, grasses) do not capture key functional traits that define plant ecological strategies. In some cases, native forbs and bunchgrasses had similar trait values, but in the majority of cases species groupings were poor indicators of important functional traits. Collectively, these observations suggest that by framing restoration and vegetation management goals in terms of key plant functional traits, rather than on functional groups, we likely will improve our ability to establish and maintain invasionresistant plant communities.

\section{Management Implications}

Our work and the work of other researchers suggests that focusing on key functional traits may help land managers better design invasion-resistant plant communities. Early work established some important guidelines for achieving these goals. These studies focused on species abundance, timing of plant growth, rooting patterns, and plant growth rate as key factors in designing invasion-resistant communities. Because more-abundant species sequester more resources, establishing dominant species that differ in phenology and rooting depth means resources will be used more completely through the season. These communities will leave fewer resources available to an invader, compared to communities in which abundant species are not well differentiated in their pattern of resource capture.

We can integrate our core findings here with this previous work to propose a decision-making framework for designing weed-resistant plant communities. In addition to using abundance, phenology, rooting patterns, and growth rate, we also can incorporate the concepts of SLA and nutrient use efficiency into our design criteria. Because we know SLA is a very good predictor of plant growth and resource capture rates, we may decide to select abundant species with high SLA differing in phenology and rooting depth. In some cases, only three or four species may be required to fill these criteria. For example, combining a high-SLA bunchgrass, a high-SLA forb, a shrub, and some desired annuals may improve invasion resistance sufficiently. However, in most cases, revegetation and restoration efforts have multiple goals, not just invasion resistance. These findings still can be applied in these more complex scenarios. If multiple species of a functional group need to be established for forage or habitat needs, SLA rankings still can be used to predict which species groups likely will be most effective in interfering with invader establishment and growth.

Our observations of plant nutrient use efficiencies and ability to selectively place roots where nutrients are most abundant provide some largely unexpected results with direct management implications. Most previous thinking in invasive plant ecology centered on the idea that native plants were generally better adapted to low nutrient conditions on rangeland and that increases in nutrient availability were needed for invasives to spread. However, we found invasives overall had a greater ability to place roots in nutrientenriched soil patches and that invasive plants were often twice as nutrient use efficient as natives. These data suggest that although managing resource availability may be important for slowing the spread of invaders, this activity by itself will not provide an advantage to desired species. Overall, the ability of desired species to compete with an invader in nutrient-poor systems may largely be driven by the ability to efficiently place roots in nutrient-rich microsites and use these captured nutrients efficiently. Combining these traits with SLA may be critical in designing weed-resistant plant communities in nutrient-poor systems. 
Our proposed framework does not address all factors driving invasion but does provide an important first step in answering questions about which types of plant material may provide the greatest resistance to a particular invader. We recognize that site conditions can vary, both spatially and, particularly with respect to climate change, temporally. What we wish to emphasize is the importance of functional traits in the decision-making process, not simply species or functional group diversity. We propose that by focusing on functional traits, we can better select species that will be most competitive under these different scenarios. For example, if herbivory is an important driver of population and community dynamics, focusing on high SLA alone will not provide a successful outcome, as high SLA is achieved through producing "cheap," less well-protected leaves. Under this scenario, selecting a generalist species that better protects its leaves but still achieves a fairly high growth rate may be more successful. Likewise, if low soil nutrient concentrations are the key driver, selecting species that can effectively forage for nutrients and achieve high nutrient use efficiency will be most important.

Plant material programs and seed increase projects are progressing at a rapid rate. Advances in linking functional traits to major plant ecological strategies can help us understand how to use these materials most effectively. Instead of considering plant community composition in terms of species or functional groups, this line of research provides a compelling case to consider community composition in terms of functional traits. By focusing screening efforts on important functional traits as plant material becomes available, we may be able to catalogue and organize this information into a decision-making framework, allowing us to predict effects of various reseeding mixtures on invasion resistance.

\section{References}

1. Sheley, R. L., J. M. Mangold, and J. L. Anderson. 2006. Potential for successional theory to guide restoration of invasive-plant-dominated rangeland. Ecological Monographs 76:365-379.

2. Stohlgren, T. J., D. Binkley, G. W. Chong, M. A. Kalkhan, L. D. Schell, K. A. Bull, Y. Otsuki, G. Newman, M. Baskin, and Y. Son. 1999. Exotic species invade hot spots of native plant diversity. Ecological Monographs 69:25-46.
3. Wright, J. P., S. Naeem, A. Hector, C. Lehman, P. B. Reich, B. Schmid, and D. Tilman. 2006. Conventional functional classification schemes underestimate the relationship with ecosystem functioning. Ecology Letters 9:111-120.

4. James, J. J., K. W. Davies, R. L. Sheley, and Z. T. Aanderud. 2008. Linking nitrogen partitioning and species abundance to invasion resistance in the Great Basin. Oecologia 156:637-648.

5. Dukes, J. S. 2002. Species composition and diversity affect grassland susceptibility and response to invasion. Ecological Applications 12:602-617.

6. Pokorny, M. L., R. L. Sheley, C. A. Zabinski, R. E. Engel, T. J. Svejcar, and J. J. Borkowski. 2005. Plant functional group diversity as a mechanism for invasion resistance. Restoration Ecology 13:448-459.

7. Diaz, S., J. G. Hodgson, K. Thompson, M. Cabido, J. H. C. Cornelissen, A. Jalili, G. Montserrat-Marti, J. P. Grime, F. Zarrinkamar, Y. Asri, S. R. Band, S. Basconcelo, P. Castro-Diez, G. Funes, B. Hamzehee, M. Khoshnevi, N. Perez-Harguindeguy, M. C. Perez-Rontome, F. A. Shirvany, F. Vendramini, S. Yazdani, R. AbbasAzimi, A. Bogahrd, S. Boustani, M. Charles, M. Dehghan, L. de Torres-Espuny, V. Falczuk, J. Guerrero-Campo, A. Hynd, G. Jones, E. Kowsary, F. KazemiSaeed, M. Maestro-Martinez, A. Romo-Diez, S. Shaw, B. Siavash, P. Villar-Salvador, and M. R. Zak. 2004. The plant traits that drive ecosystems: evidence from three continents. Journal of Vegetation Science 15:295-304.

8. Wright, I. J., P. B. Reich, M. Westoby, D. D. Ackerly, Z. Baruch, F. Bongers, J. Cavender-Bares, T. Chapin, J. H. C. Cornelissen, M. Diemer, J. Flexas, E. Garnier, P. K. Groom, J. Gulias, K. Hikosaka, B. B. Lamont, T. Lee, W. Lee, C. Lusk, and J. J. Midgley. 2004. The worldwide leaf economics spectrum. Nature 428:821-827.

9. James, J. J., And R. E. Drenovsky. 2007. A basis for relative growth rate differences between native and invasive forb seedlings. Rangeland Ecology and Management 60:395-400.

10. Drenovsky, R. E., C. E. Martin, M. R. Falasco, and J. J. James. 2008. Variation in resource use and acquisition traits between native and invasive perennial forbs. American Journal of Botany 95:681-687.

Authors are Assistant Professor, Biology Department, John Carroll University, 20700 North Park Blvd, University Heights, OH 44118, USA, rdrenorsky@jcu.edu (Drenorsky); and Research Plant Physiologist, USDA Agricultural Research Service, Eastern Oregon Agricultural Research Center, 67826-A Hwy 205, Burns, OR 97720, USA (James). 